\title{
The Influences of Service Personalization, Customer Satisfaction and Switching Costs on E-Loyalty
}

\author{
Canon Tong \\ International Graduate School of Business, University of South Australia \\ Adelaide SA, Australia \\ E-mail: canon.tong@unisa.edu.au \\ Stanley Kam-Sing Wong (Corresponding author) \\ Faculty of Business and Law, University of Newcastle \\ Callaghan NSW, Australia \\ E-mail: stanleykswong@gmail.com \\ Ken Pui-Hing Lui \\ International Graduate School of Business, University of South Australia \\ Adelaide SA, Australia \\ E-mail: ken.ph.lui@gmail.com
}

Received: December 8, 2011

Accepted: January 4, 2012 Published: March 1, 2012

doi:10.5539/ijef.v4n3p105

URL: http://dx.doi.org/10.5539/ijef.v4n3p105

\begin{abstract}
This research investigates the interrelationship amongst the variables of service personalization, customer satisfaction and e-loyalty and the moderating effect of switching costs on the said relationships in the Internet banking segment in Hong Kong. Findings from 306 respondents confirm the significant positive effect of service personalization on customer satisfaction and e-loyalty, and customer satisfaction is found to have a positive effect on e-loyalty. However, evidence of switching costs as a moderator does not exist, suggesting that the effects of switching costs on the relationship between customer satisfaction and e-loyalty, and between service personalization and e-loyalty may be more complex than originally hypothesized. This research contributes to consumer marketing research in banking by adding empirical evidence of the positive role that service personalization plays on e-loyalty in the Internet banking sector.
\end{abstract}

Keywords: Service personalization, Switching costs, Customer satisfaction, Customer loyalty, E-loyalty, Internet banking, Hong Kong

\section{Introduction}

Customer loyalty is an essential ingredient of almost all kinds of businesses. Studies have found that it is expensive to acquire new customers and new customers usually buy less. Retaining existing customers, however, is much cheaper and easier (Ahmad and Buttle, 2002). To most banks, these customers represent a stable source of income and growth. Prior research has revealed that there is a strong association between customer satisfaction and brand loyalty (Anderson and Sullivan, 1993; Leverin and Liljander, 2006; Ribbink, Allard, Veronica and Sandra, 2004). Having a large pool of loyal customers is generally regarded as a major source of sustainable competitive advantage (Anderson and Mittal, 2000). In the banking industry, customer retention has been found to be a key determinant for long-term profitability, as selling products to existing customers costs much less than selling to new customers (Lam, Burton and Lo, 2009).

In the past thirty years, the use of the Internet has dramatically revolutionized how businesses are conducted in the banking sector (Methlie and Nysveen, 1999). The very nature of Internet banking brings banking services to the personal space of individual account owners. With the aid of a computer or any Internet-equipped devices, one can access his bank accounts and perform banking transactions virtually any time any where. This disintegration of the geographical and time barriers have brought great convenience to customers. From the banks' perspective, however, 
Internet banking not only brings about additional costs but also pushes the battle line of customer retention beyond the traditional service counter to the personal spaces of individual customers. The new competitive landscape demands a firm grasp of the needs of their existing customers and practical ingenuity that enables banks to keep their customers from switching by a simple 'click-and-go' (Friedman, 1999).

\subsection{The Challenges of the Banking Segment in Hong Kong and the Research Gap}

A saturated market with cyclic upheavals in the past few years has induced banks in Hong Kong to compete fiercely both locally and internationally. And, in addition to successive reductions of interest rate spread (Wong, Fong, Wong and Choi, 2007) and rising wages (Tsang, 2010), high property rents have significantly eroded potential profits of the banks in Hong Kong as many of these banks are headquartered or having their main branches set up in prime locations. To increase profit as well as to meet many other challenges they are facing, Internet banking has become their strategy of choice.

To the banks that have chosen Internet banking, the Internet provides them with a low-cost option for serving their customers. It helps them to streamline operating costs and improve efficiency. It reduces the costs of paperwork related to transactions and offers ample opportunities for banks to retain existing customers and attract new ones. Customers find that Internet banking adds value to their lives as it gives them access to banking and financial services 24 hours a day, 7 days a week (24/7).

Nothing breeds customer loyalty and satisfaction more than quality customer service. Quality customer service in Internet banking refers to a bank's ability to create a secure and convenient online platform that not only provides what competitors are providing but also what customers are expecting. The importance of customer loyalty in marketing is well acknowledged by researchers (Reichheld and Schefter, 2000), the influence of some antecedents to customer loyalty, however, remains unclear. Although prior research has identified customer satisfaction, service personalization, and switching costs as key drivers of customer loyalty, findings regarding the effect of switching costs on customer loyalty have been contradictory (e.g. Johnson, Sivadas and Garbarino, 2008; He, Cheung and Tse, 2009). This study examined the direct and indirect influences of service personalization on customer loyalty in Internet banking (e-loyalty). The study used Anderson and Srinivasan's (2003) definition of e-loyalty as an Internet banking user's favorable attitude toward an Internet banking service; a favorable attitude is demonstrated by a patron's continued and repeated use of a particular Internet banking service.

On the other hand, research to date has largely neglected the moderating influences of switching costs on the relationship between service personalization and e-loyalty and on that between customer satisfaction and e-loyalty. This study developed a conceptual model that tested all these variables and examined the direct and indirect relationships among the pivotal components to the breeding of loyal customers, namely switching costs, customer satisfaction and service personalization using samples drawn from Hong Kong Internet banking users. The study contributes to consumer marketing research in banking by adding empirical evidence of the positive role that service personalization plays on e-loyalty in the Internet banking sector.

\section{Theoretical Framework}

\subsection{Service Personalization}

The rapid growth of information technology (IT) has not only changed the ways that information is collected and used, but also the ways in which businesses are conducted. With the Internet serving as a conduit and with the growing abundance of IT-based products, such as faster and cheaper computers, the increasing popularity and availability of smartphones and tablet computers, companies are now able to provide services to customers that they have never been possible to provide before. Being a key enabler of service personalization, IT has made one-to-one marketing in banking a reality. The next step in this trend will be to use customer relationship management infrastructure to find out what customers value and tailor the service to their particular needs (Montgomery and Smith, 2009; Peppers and Rogers, 1997) with the aim of further enhancing their loyalty.

A bank which is capable of providing truly personalized service differentiates itself from other banks as each of its customers is provided with sets of banking services catering to their unique needs (Hanson, 2000). With high service differentiation, the bank can then compete in the blue ocean instead of the red sea and earn higher profit than its competitors (Kim and Mauborgne, 2005). Therefore, our first hypothesis was:

Hypothesis 1: Service personalization has a positive influence on e-loyalty of Internet banking users in Hong Kong.

\subsection{Customer Satisfaction}

Studies have found that customer satisfaction is an ex-post evaluation of service experience and is a key factor in 
retaining customers and improving customer loyalty (Mak, Wong and Tong, 2012). Satisfied customers are more likely to stay and continue to use a bank's services, while unsatisfied customers will walk away and find a different service provider (Methlie and Nysveen, 1999; Leverin and Liljander, 2006). Keeping customers loyal is a challenge for banks as it is becoming common for bank customers to maintain more than one bank account with more than one bank. The challenge in Hong Kong is particularly big as the Hong Kong Deposit Protection Board provides full guarantee to account holders with a deposit not exceeding HK\$500,000 (around US\$64,000) in case of a bank default (Lui, 2010). To depositors who have assets exceeding HK $\$ 500,000$, putting their money in multiple accounts across a number of banks in order to qualify for the guarantee is a matter worthy of serious consideration.

To the banks, a customer with multiple bank accounts in different banks is more likely to switch one or all of his accounts to another bank if he is not satisfied with the service provided (Lam et al., 2009). In this study, customer satisfaction was considered as contentment with the overall experience gained from using banking services over time (Oliver, 1980; Anderson and Srinivasan, 2003). If a bank can provide personalized services to its customers and make its customers feel that the newly provided personalized services are useful and user-friendly, their level of satisfaction increases (Davis 1989; Davis, Bagozzi and Warshaw, 1989). Therefore, our second hypothesis was:

\section{Hypothesis 2: Service personalization has a positive influence on customer satisfaction of Internet banking users in Hong Kong.}

Loyal customers may not be satisfied customers, but satisfied customers tend to be loyal customers (Fornell, 1992). Previous studies in various settings have revealed that customer satisfaction has a positive influence on customer loyalty (e.g. Leverin and Liljander, 2006; Anderson and Sullivan, 1993). As it is more difficult for a competitor to attract satisfied customers than unsatisfied customers (Methlie and Nysveeen, 1999), our third hypothesis, therefore, was:

Hypothesis 3: Customer satisfaction has a positive influence on e-loyalty of Internet banking users in Hong Kong.

\subsection{Switching Costs}

Switching costs play an important role in customer retention. When switching costs are perceived to be high, customers are reluctant to switch to a competing service provider, whereas when the costs of switching are perceived to be low, customers are more likely to switch to a different provider (Colgate and Lang, 2001). In the old days, large banks in Hong Kong could easily differentiate themselves from the smaller ones because the former were generally perceived as more stable and therefore reliable. This brand image served as a significant switching barrier to depositors and explained why depositors were willing to accept a lower interest rate for deposits with larger banks such as HSBC and Citicorp. But competition has changed after Hong Kong Deposit Protection Board launched the bank deposit guarantee scheme in 2006 (Lui, 2010). The scheme has made it more difficult for a bank in Hong Kong to differentiate itself from competitors, especially on the traditional deposit and lending front.

Customers who hold multiple bank accounts are generally perceived as having lower switching costs as they can easily switch from one bank to another (Lam and Burton, 2006). As switching costs can be one of the antecedents to customer loyalty in the banking industry, it is important for banks to find ways to increase customer switching costs (Beerli, Martin and Quintana, 2004). One way to achieve this is to provide highly personalized services to meet the needs of individual customers. In the context of Internet banking, service personalization can be done through customized interface, targeted banner, etc.. Our fourth hypothesis, therefore, was:

\section{Hypothesis 4: Switching costs have a positive influence on customer loyalty of Internet banking users in Hong Kong.}

\subsection{Moderating Effects of Switching Costs}

Switching costs have often been regarded as one of the reasons of why dissatisfied customers do not switch to another service provider (Beerli et al., 2004; Caruana, 2004; Burnham, Frels and Mahajan, 2003; Colgate and Lang, 2001). But the level of influence of switching costs varies depending on the industry involved (Burnham et al., 2003; Jones, Mothersbaugh and Beatty, 2002). In the banking sector, trust plays an important role and costs associated with risk and uncertainty may have a big influence on customer behavior (Singh and Sirdeshumukh, 2000; Gronghaug and Gilly, 1991). Customers who perceive a high level of switching costs may behave differently from those who only perceive a low level of switching costs. To test this, the following two pairs of hypotheses were proposed:

Hypothesis 5a: Switching costs moderate the influence of service personalization on e-loyalty of Internet banking users in Hong Kong. 
Hypothesis 5b: Switching costs do not moderate the influence of service personalization on e-loyalty of Internet banking users in Hong Kong.

Hypothesis 6a: Switching costs moderate the influence of customer satisfaction on e-loyalty of Internet banking users in Hong Kong.

Hypothesis 6b: Switching costs do not moderate the influence of customer satisfaction on e-loyalty of Internet banking users in Hong Kong.

\subsection{Research Framework}

Insert Figure 1 Here

Based on the above hypotheses, a research framework with four variables outlined in Figure 1 was developed.

\section{Methodology}

Quantitative research method using an online questionnaire was adopted to examine the direct and indirect influences of service personalization on e-loyalty as well as the moderating role of switching costs on the above relationships. A total of 2,500 email invitations were sent to randomly selected potential participants.

\subsection{Measurement Instrument}

In order to fully capture the essential features and multidimensional aspects of the above variables, every single variable was measured by way of multi-item scales adapted from prior studies. Service personalization was the only independent variable. The three questionnaire items for service personalization were adapted from Srinivasan, Anderson and Ponnavolu (2002). E-loyalty was the dependent variable. The 6 questionnaire items of e-loyalty were adapted from Anderson and Srinivasan (2003). Switching costs were featured as the moderating variable. The 4 questionnaire items of switching costs were adapted from Ping (1993). Customer satisfaction was hypothesized as an intermediate variable on the causal pathway between service personalization and e-loyalty. The five questionnaire items of customer satisfaction were adapted from Anderson and Srinivasan (2003).

As the content and construct validity of each variable had already been evaluated by the original authors, it was reasonable to assume that both content and construct validities of the multidimensional-item scales should accurately represent the variables concerned (Wong and Tong, 2012).

\subsection{Samples and Sampling Technique}

For this study, a simple random sampling technique was chosen to obtain a sample size of 2,500 potential respondents. The email addresses of the potential respondents were randomly selected from email address databases collected from public domain websites. As the focus of this study was Internet banking users, only responses from those who used Internet banking services were taken into account. Out of the 2,500 email invitations sent, a total of 306 responses were received, representing a response rate of approximately $12 \%$.

\section{Data Analysis}

The responses collected were processed to look for both direct and moderating effects using the Statistical Package for the Social Sciences (SPSS) for Windows Version 14.

\subsection{Reliability}

Cronbach's alpha was used to measure the internal consistency or reliability of the items in each variable of the questionnaire (Verbeke and Bagozzi, 2000). As a general rule, variables with a Cronbach's alpha coefficient higher than 0.7 are considered as having a good internal consistency among items (Nunnally and Bernstein, 1994; Shin, Collier and Wilson, 2000). Table 1 summarizes the Cronbach's alpha coefficients with respect to each of the four variables. All four variables had a Cronbach's alpha coefficient between 0.795 and 0.897 and were therefore considered acceptable for further analysis.

Insert Table 1 Here

\subsection{Factor Analysis for Reliability Testing}

Principle component analysis with Varimax rotation was conducted using SPSS on all items of the four variables in the questionnaire. Items with factor loading less than 0.5 were deleted (Hair, Black, Babin, Anderson and Tatham, 2006).

Bartlett's test of sphericity and the Kaiser-Meyer-Olkin (KMO) measure of sampling adequacy are the two most common tests performed to see whether the basic assumptions for factor analysis are met (Coakes, Steed and Price, 2008; Hair et al., 2006). The results showed in Table 1 indicate that Bartlett's test was significant (sig. $=.000)$ and the KMO values were in the range between 0.653 and 0.868 , which were all higher than 0.6 (Coakes et al., 2008), 
indicating that the performance items were suitable for factor analysis.

\subsection{Data Analysis}

Linear regression was used to test the positive association of hypotheses $\mathrm{H} 1$ to H4. Multiple linear regression was conducted to test hypotheses H5a, H5b, H6a and H6b to investigate the possible moderating effects of switching costs on the causal pathway between service personalization and e-loyalty and between customer satisfaction and e-loyalty using the method proposed by Baron and Kenny (1986).

\section{Results}

The linear regression test results in Table 2 confirm that the service personalization had a significant positive impact on both e-loyalty $(=0.487, \mathrm{p}<0.05)$ and customer satisfaction $(=0.330, \mathrm{p}<0.05)$. Service personalization explained $23.7 \%$ of variance in e-loyalty of Internet banking users in Hong Kong $\left(\mathrm{R}^{2}=0.237\right)$ and $10.9 \%$ of variance in customer satisfaction of Internet banking users in Hong Kong $\left(R^{2}=0.109\right)$, giving support to both hypotheses 1 and 2 .

It was also confirmed that customer satisfaction and switching costs had a significant positive impact on e-loyalty (= 0.623 and 0.288 respectively, $\mathrm{p}<0.05$ ). Customer satisfaction explained $38.8 \%$ of variance in e-loyalty of Internet banking users in Hong Kong $\left(\mathrm{R}^{2}=0.388\right)$ and switching costs explained $8.3 \%$ of variance in e-loyalty of Internet banking users in Hong Kong $\left(\mathrm{R}^{2}=0.083\right)$, giving support to hypotheses 3 and 4 .

Insert Table 2 Here

Table 3 shows the multiple regression analysis results using the approach proposed by Baron and Kenny (1986) for the test of the moderating effects of switching costs on the respective influences of service personalization (H5a and $\mathrm{H} 5 \mathrm{~b}$ ) and customer satisfaction (H6a and H6b) on e-loyalty.

Insert Table 3 Here

Insert Table 4 Here

From the three models in Table 3, Model 1 indicates significant total effects of service personalization on e-loyalty $\left(\mathrm{R}^{2}=0.237,=0.418, \mathrm{p}<0.05\right)$; and Model 2 shows a significant increase in $\mathrm{R}^{2}$ value from 0.237 to 0.262 . When the moderator of switching costs was added, the explanation power of the model increased slightly by $2.5 \%$ to $26.2 \%$ $\left(\mathrm{R}^{2}=0.262, \mathrm{p}<0.05\right)$. When the interaction item of "Pers X sCost" was added to Model 3, the explanation power of the Model increased slightly by $0.2 \%$ to $26.4 \%\left(\mathrm{R}^{2}=0.264\right)$. The increase in explanation power was not only small, but also insignificant $(=-0.049, \mathrm{p}=0.375)$. In other words, there exists no significant moderating effects of switching costs on the relationship between service personalization and e-loyalty. Therefore, Hypothesis 5a was rejected and Hypothesis $5 \mathrm{~b}$ was supported.

From the three models in Table 5, Model 1 indicates a significant total effect of customer satisfaction on e-loyalty $\left(R^{2}=0.388,=0.623, p<0.05\right)$; and Model 2 shows a significant increase of $R^{2}$ value from 0.388 to 0.434 . When the moderator of switching costs was added, the explanation power of the Model increased by $4.6 \%$ to $43.4 \%\left(\mathrm{R}^{2}=\right.$ $0.434, \mathrm{p}<0.05)$. When the interaction item of "Sat X sCost" was added to Model 3, the explanation power of the Model increased slightly by $0.3 \%$ to $43.7 \%\left(\mathrm{R}^{2}=0.437\right)$. The increase in explanation power was small and insignificant $(=0.059, p=0.192)$. In other words, there exists no significant moderating effect of switching costs on the relationship between customer satisfaction and e-loyalty. Therefore, Hypothesis 6a was rejected and Hypothesis $6 \mathrm{~b}$ was supported.

\section{Discussion}

This study contributes to consumer marketing research in banking in multiple ways. Firstly, it addressed a gap by adding empirical evidence of the positive role that service personalization plays on e-loyalty in the Internet banking sector in Hong Kong. The study found that service personalization has a significant effect on customer satisfaction and customer satisfaction has a significant influence on e-loyalty in the Internet banking sector in Hong Kong.

Most previous studies were on the direct relationships among customer satisfaction, switching costs and customer loyalty. In addition to direct relationships, this study further explored the indirect relationships among the variables featured. Findings of the study revealed that the moderating effect of switching costs on the relationship between service personalization and e-loyalty and that between customer satisfaction and e-loyalty is insignificant. The finding contrasted with prior studies (e.g. Colgate and Lang, 2001; Lee and Cunningham, 2001) which asserted that switching costs has a significant moderating effect on the relationship between customer satisfaction and customer loyalty. The contradictory result indicates that switching costs may probably be a more complicated concept than originally hypothesized (Jones et al., 2002; Burnham et al., 2003). One of the possible explanation is that most of the prior studies were conducted in the traditional transaction settings, and people may perform differently in the 
Internet world. Further studies are recommended to verify this.

Lastly, the lack of moderating effects of switching costs on the association between customer satisfaction and e-loyalty and on that between service personalization and e-loyalty, may also underline the complexity of the interrelationships hypothesized. It is possible that switching costs play a mediating role instead of a moderating role on such relationships. In other words, service personalization may accustom Internet banking users to the personalized services provided. Getting used to personalized services creates inertia for customers to continue using these services. The same inertia may then keep these users from switching to other banks. On the other hand, being accustomed to the personalized services and customized webpage of a bank may also make it more difficult for customers to learn and ultimately be satisfied with the services provided by competing banks. This in turn increases customer loyalty.

In practical terms, the confirmation that the perception of service personalization has a significant positive impact on the level of satisfaction an Internet banking user may have toward the services provided suggests that, despite the common view that Internet banking is nothing more than a supplement to traditional over-the-counter banking services, service personalization is an important driver of customer satisfaction. As such, to satisfy customers and to ensure the long-term profitability of banks, banking practitioners in Hong Kong need to enhance service personalization in order to increase the satisfaction level of their Internet banking customers.

Furthermore, this study found that both perceptions of service personalization and customer satisfaction have a very strong and significant positive impact on the level of e-loyalty an Internet banking user may have toward an Internet banking service provider $(=0.487$ and 0.623 respectively, $\mathrm{p}<0.05$ ). The finding suggests that the provision of more personalized services to Internet banking users not only increases their satisfaction toward a bank's services, but also considerably increases their loyalty toward the bank. As such, to retain customers and to capture a greater share of the market, banking practitioners in Hong Kong should enhance their efforts in providing personalized service as these efforts would lead to an increase in customer loyalty.

There are many ways for banks to provide personalized services. Personalization of Internet banking services can be done by simply allowing individual customers to customize the layout of the webpage so that every customer can have his or her unique Internet banking webpage after logging onto the Internet banking server. Service personalization can also be done by the creation of a new service that meets a specific need of an individual customer. For example, banks can provide online personalized financial advice to individual customers based on their transaction history and their personal preferences.

Online banking is branded for its low cost (Gilmore and Pine, 2000) and low cost is a major enabler for mass customization. Through mass customization, a bank can divide its services into different service modules and components, and each service module can be a combination of different service components. For example, a bank can divide its online security trading services into different service components covering stock price quotation, stock purchase, sales of stock, and advice. Each module, say, stock price quotation, may offer different components as options, e.g., real time quotation, delayed quotation with varying time lags (5 minutes, 15 minutes, etc.), and daily transaction history of each stock with different levels of details (from a hourly transaction volume report to a full report listing out the transaction time, volume, price, and security agencies used for each and every stock traded). The bank can charge different customers at different levels of costs basing on, for example, the type of service a particular customer selected, the transaction history of the customer or any other customer parameters. As most of the personalized services cited can be provided by computer-based mass customization, personalized service can be provided to individual customers at low cost.

Another management implication that stems from this study is the confirmation of the significant positive impact that customer satisfaction exerts on the e-loyalty of Internet banking users. The finding suggests that loyalty of a user toward an Internet banking provider increases with growing levels of service satisfaction. If a customer is satisfied with the Internet banking services provided, he will use more of the services from the same vendor. To retain customers and to increase their share of the market, banks in Hong Kong should find ways to leverage on the factor of customer satisfaction as satisfaction breeds loyalty.

\section{Limitations}

While the study is expected to contribute to both academic research and management practice in the Internet banking segment in Hong Kong, its findings may be limited in several ways. The use of positivist ontology, the deductive and confirmatory nature of the study and the adoption of quantitative methodology impose the first limitation. Though quantitative methods were used to ascertain the relationships among the variables featured in the model, it is still unclear whether the hypothesized relationships truly represent the linkages among the variables and whether there exist other antecedents to e-loyalty that may affect the behavior of customers of Internet banking in 
Hong Kong.

The cross-sectional nature of this study imposes the second limitation. Similar to all other cross-sectional studies, this study captured and analyzed a snapshot of a phenomenon only (Sriram and Stump, 2004), without examining its changes over time. The third limitation is that this study only focused on investigating the links among service personalization, customer satisfaction, switching costs and e-loyalty, despite the possibility that e-loyalty may also depend on other antecedents such as demographic factors (i.e. gender, age, monthly income and so on) and previous experiences. The possible existence of other antecedents may impose limitations on the generalizability of the findings.

Finally, although the sample size of this study $(\mathrm{n}=306)$ was larger than other similar studies (e.g. Cheng, Lam and Yeung, 2006), the findings which emanated from Internet banking users in Hong Kong may only be valid to the banking industry in Hong Kong and hence may not be generalized to other industries in Hong Kong or the banking industry in other places.

\section{Further Research}

There are several opportunities for further study to overcome the limitations identified and discussed in the previous section. First, it is suggested that a further study using a mixed-method approach should be conducted by combining both quantitative and qualitative methods to leverage the advantages of triangulation (Bryman, 2008). Qualitative tools, for example in-depth interviews, can be used to identify additional antecedents to loyalty in the Internet banking industry. The antecedents identified can then be used for the development of a more comprehensive framework before being empirically tested by quantitative methods with a wider population.

The second research opportunity is to take into account the time lag between cause and effect and conduct a longitudinal study by capturing the dynamic interplay of relationships among the constructs in the research framework (Bryman, 2008). This approach will allow the researcher to trace and track the changes in the perception of the sampled population over time and enable the researcher to gain a better understanding of the patterns, determinants and dynamics of change in e-loyalty.

Finally, contrary to findings from mainstream research, this study revealed that switching costs do not moderate the relationship between service personalization and e-loyalty or that between customer satisfaction and e-loyalty. This indicates that the relationships among the variables of service personalization, customer satisfaction, switching costs and e-loyalty may be more complicated than that was hypothesized in the study. Further research to find out the true behavior of switching costs would give more insights in both theory and practice for future applications.

\section{References}

Ahmad, R., \& Buttle, F. (2002). Retaining telephone banking customers at Frontier Bank. International Journal of Bank Marketing, 20(1). 5-16. http://dx.doi.org/10.1108/02652320210415944

Anderson, E.W., \& Mittal, V. (2000). Strengthening the satisfaction-profit chain. Journal of Service Research, 3(2). 107-120. http://dx.doi.org/10.1177/109467050032001

Anderson, E.W., \& Sullivan, M.W. (1993). The antecedents and consequences of customer satisfaction for firms. Marketing Science, 12. 125-143. http://dx.doi.org/10.1287/mksc.12.2.125

Anderson, R.E., \& Srinivasan, S.S. (2003). E-satisfaction and e-loyalty: A contingency framework. Psychology and Marketing, 20(2). 123-138. http://dx.doi.org/10.1002/mar.10063

Beerli, A, Martin, J.D., \& Quintana, A. (2004). A model of customer loyalty in the retail banking market. European Journal of Marketing, 38. 253-275. http://dx.doi.org/10.1108/03090560410511221

Baron, R.M., \& Kenny, D.A. (1986). The moderator-mediator variable distinction in social psychological research: Conceptual, strategic and statistical considerations. Journal of Personality and Social Psychology, 51(6). 1173-1182. http://dx.doi.org/10.1037/0022-3514.51.6.1173

Burnham, T.A., Frels, J.K., \& Mahajan, V. (2003). Consumer switching costs: A typology, antecedents, and consequences. Journal of the Academy of Marketing Science, 31(2). 109-126. http://dx.doi.org/10.1177/0092070302250897

Bryman, A. (2008). Social Research Methods, New York: Oxford University Press.

Cheng, T.C.E., Lam, D.Y.C., \& Yeung, A.C.L. (2006). Adoption of internet banking: An empirical study in Hong Kong. Decision Support Systems, 42(3). 1558-1572. http://dx.doi.org/10.1016/j.dss.2006.01.002

Caruana, A. (2004). The impact of switching costs on customer loyalty: A study among corporate customers of mobile telephony. Journal of Targeting, Measurement and Analysis for Marketing, 12(3). 256-268. 
http://dx.doi.org/10.1057/palgrave.jt.5740113

Coakes, S.J., Steed, L., \& Price, J. (2008). SPSS Version 15.0 for Windows: Analysis without Anguish. John Wiley and Sons Australia, Ltd.

Colgate, M., \& Lang, B. (2001). Switching barriers in consumer markets: An investigation of the financial services industry. Journal of Consumer Marketing, 18(4). 332-347. http://dx.doi.org/10.1108/07363760110393001

Davis, F.D. (1989). Perceived usefulness, percieved ease of usem and user accpetance of informatin technology. MIS Quarterly, 13(3). 319-340. http://dx.doi.org/10.2307/249008

Davis, F.D., Bagozzi, P.R., \& Warshaw P.R. (1989). User acceptance of computer technology: A comparison of two theoretical models. Management Science, 35(8). 983-1003. http://dx.doi.org/10.1287/mnsc.35.8.982

Fornell, C. (1992). A National customer satisfaction barometer: The Swedish experience. The Journal of Marketing, 56(1). 6-21.

Friedman, T. (1999). Amazon.you. New York Times. February 26. A21.

Gilmore, J., \& Pine, J. (2000). Markets of one: Creating customer-unique value through mass customization, Boston: Harvard Business School Press.

Golder, P.N. (2000). Historical method in marketing research with new evidence on long-term market share stability. Journal of Marketing Research, 37(2). 156-172. http://dx.doi.org/10.1509/jmkr.37.2.156.18732

Gronghaug, K., \& Gilly, M.C. (1991). A transaction cost approach to consumer dissatisfaction and complaint actions. Journal of Economic Psychology, 12(1). 165-183. http://dx.doi.org/10.1016/0167-4870(91)90048-X

Hair, J.F., Black, B., Babin, B., Anderson, R.E., \& Tatham, R.L. (2005). Multivariate Data Analysis. Prentice Hall.

Hanson, W. (2000). Principles of Internet marketing. Ohio: South-western College Publishing.

He, Y., Cheung, S.M., \& Tse, S.K. (2009). The role of switching costs on service loyalty: a canonical correlation analysis. Journal of Chinese Entrepreneurship. 1(2). 154-164. http://dx.doi.org/10.1108/17561390910956305

Johnson, M.S., Sivadas, E., \& Garbarino, E. (2008). Customer satisfaction, perceived risk and affective commitment: an investigation of directions of influence. Journal of Services Marketing, 22(5). 353-362. http://dx.doi.org/10.1108/08876040810889120

Jones, M.A., Mothersbaugh, D.L., \& Beatty, S.E. (2002). Why customers stay: Measuring the underlying dimensions of services switching costs and managing their differential strategic outcomes. Journal of Business Research, 55(6). 441-450. http://dx.doi.org/10.1016/S0148-2963(00)00168-5

Kim, W.C., \& Mauborgne, R. (2005). Blue Ocean Strategy. Boston: Harvard Business School Press.

Lam, R., \& Burton, S. (2006). SME banking loyalty (and disloyalty): A qualitative study in Hong Kong. International Journal of Bank Marketing, 24(1). 37-52.

Lam, R., Burton, S., \& Lo, H.P. (2009). Customer tradeoffs between key determinants of SME banking loyalty. International Journal of Bank Marketing, 27(6). 428-445. http://dx.doi.org/10.1108/02652320910988311

Lee, M., \& Cunningham, L.F. (2001). A cost/benefit approach to understanding service loyalty. Journal of Services Marketing, 15(2). 113-130. http://dx.doi.org/10.1108/08876040110387917

Leverin, A., \& Liljander, V. (2006). Does relationship marketing improve customer relationship satisfaction and loyalty? The International Journal of Bank Marketing, 24(4). 232-251. http://dx.doi.org/10.1108/02652320610671333

Lui, M. (2010). Hong Kong to Protect Bank Deposits of Up to HK\$ 500,000. [online] Available:http://www.bloomberg.com/news/2010-12-30/hong-kong-to-protect-bank-deposits-of-up-to-hk-500-000-u pdate1-.html (December $\left.5^{\text {th }}, 2011\right)$

Mak, K., Wong, S.K.S., \& Tong, C. (2011). How Guanxi Influences Word of Mouth Intentions. International Journal of Business and Management, 6(7). 3-14. http://dx.doi.org/10.5539/ijbm.v6n7p3

Methlie, L.B., \& Nysveen, H. (1999). Loyalty of on-line bank customers. Journal of Information Technology, 14. 375-386.

Montgomery, A.L., \& Smith, M.D. (2009). Prospects for personalization on the Internet. Journal of Interactive Marketing, 23(2). 130-137. http://dx.doi.org/10.1016/j.intmar.2009.02.001

Nunnally, J.C., \& Bernstein, I.H. (1994). Psychometric theory, 3rd ed. McGraw-Hill 
Oliver, R.L. (1980). A cognitive model of the antecedents and consequences of satisfaction decisions. Journal of Marketing Research, 17(4). 460-469. http://dx.doi.org/10.2307/3150499

Peppers, D., \& Rogers, M. (1997). Enterprise one-to-one: Tools for competing in the interactive age. NY: Currency Double Day.

Ping, R. (1993). The Effects of satisfaction and structural constraints on retailer exiting, voice, loyalty, opportunism, and neglect. Journal of Retailing, 69(3). 320-352. http://dx.doi.org/10.1016/0022-4359(93)90010-G

Reibstein, D.J. (2002). What attracts customers to online stores, and what keeps them coming back? Journal of the Academy of Marketing Science. 30(4). 465-473. http://dx.doi.org/10.1177/009207002236918

Ribbink, D, Allard, R, Veronica, L., \& Sandra, S (2004). Comfort your online customer: quality, trust and loyalty on the internet. Managing Service Quality. 14(6). 446-456.

Shin, H., Collier, D.A., \& Wilson, D.D. (2000). Supply management orientation and supplier/buyer performance. Journal of Operations Management. 18(3). 317-333. http://dx.doi.org/10.1016/S0272-6963(99)00031-5

Singh, J., \& Sirdeshumukh, D. (2000). Agency and trust mechanisms in consumer satisfaction and loyalty judgements. Journal of the Academy of Marketing Science. 28(1). 150-167. http://dx.doi.org/10.1177/0092070300281014

Srinivasan, S.S., Anderson, R., \& Ponnavolu, K. (2002). Customer loyalty in e-commerce: An exploration of its antecedents and consequences. Journal of Retailing. 78(1). 41-50. http://dx.doi.org/10.1177/0092070300281014

Sriram, V., \& Stump, R. (2004). Information technology investments in purchasing: an empirical investigation of communications, relationship and performance outcomes. Omega. 32(1). 41-55. http://dx.doi.org/10.1016/j.omega.2003.09.008

Tsang, D. (2010). Lessons in toymakers' rise and fall. South China Morning Post. [Online] Dec 24, 2010. Available: http://topics.scmp.com/news/hk-news-watch/article/Lessons-in-toymakers-rise-and-fall (access: Nov 25, 2011).

Verbeke, W., \& Bagozzi, R.P. (2000). Sales call anxiety: Exploring what it means when fear rules a sales encounter. The Journal of Marketing. 64(3). 88-101. http://dx.doi.org/10.1509/jmkg.64.3.88.18032

Wong, J., Fong, T., Wong, E., \& Choi, K.F. (2007). Determinants of the performance of banks in Hong Kong. Hong Kong Monetary Authority Quarterly Bulletin. September 2007 Issue. 5-15.

Wong, S.K.S., \& Tong, C. (2012). The Influence of Market Orientation on New Product Success. European Journal of Innovation Management. 15(1), pp.99-121. http://dx.doi.org/10.1108/14601061211192852

Table 1. Cronbach's Alpha and KMO Statistics

\begin{tabular}{lrr}
\hline Variables & Cronbach's Alpha & KMO Values \\
\hline Customer Satisfaction & 0.795 & 0.653 \\
Service Personalization & 0.761 & 0.674 \\
e-loyalty & 0.897 & 0.868 \\
Switching Costs & 0.871 & 0.781 \\
\hline
\end{tabular}

Table 2. Coefficients for $\mathrm{H} 1, \mathrm{H} 2, \mathrm{H} 3$ and $\mathrm{H} 4$

\begin{tabular}{lllrrrr}
\hline Hypotheses & Independent Variables & Dependent Variables & Standardized beta ( . & $\mathrm{t}$ & Sig. & R square \\
\hline H1 & Service Personalization & e-loyalty & 0.487 & 9.725 & 0.000 & 0.237 \\
H2 & Service Personalization & Customer Satisfaction & 0.330 & 6.087 & 0.000 & 0.109 \\
H3 & Customer Satisfaction & e-loyalty & 0.623 & 13.881 & 0.000 & 0.388 \\
H4 & Switching Costs & e-loyalty & 0.288 & 5.250 & 0.000 & 0.083 \\
\hline
\end{tabular}


Table 3. Model Coefficients for $\mathrm{H} 5 \mathrm{a}$ and $\mathrm{H} 5 \mathrm{~b}$

\begin{tabular}{|ll|c|c|c|c|r|}
\hline Model & Standardized Beta & $\mathrm{t}$ & Sig. & $\mathrm{R}$ & $\mathrm{R}$ square \\
\hline 1 & (Constant) & & 0.000 & 1.000 & \multirow{2}{*}{0.487} & 0.237 \\
& Service Personalization & 0.487 & 9.725 & 0.000 & & \\
\hline 2 & (Constant) & & 0.000 & 1.000 & & 0.262 \\
& Service Personalization & 0.441 & 8.580 & 0.000 & 0.512 & \\
& Switching Costs & 0.165 & 3.209 & 0.001 & & \\
\hline 3 & (Constant) & & 0.242 & 0.809 & & \\
& Service Personalization & 0.418 & 7.228 & 0.000 & & 0.514 \\
& Switching Costs & 0.174 & 3.322 & 0.001 & & \\
& Pers X SwCost & -0.049 & -0.889 & 0.375 & & \\
\hline
\end{tabular}

a Dependent Variable: e-loyalty

Table 4. Model Coefficients for H6a and H6b

\begin{tabular}{|c|c|c|c|c|c|c|}
\hline \multicolumn{2}{|c|}{ Model } & Standardized Beta & $\mathrm{t}$ & Sig. & $\mathrm{R}$ & R square \\
\hline \multirow[t]{2}{*}{1} & (Constant) & & 0.000 & 1.000 & \multirow{2}{*}{0.623} & \multirow{2}{*}{0.388} \\
\hline & Customer Satisfaction & 0.623 & 13.881 & 0.000 & & \\
\hline \multirow[t]{3}{*}{2} & (Constant) & & 0.000 & 1.000 & \multirow{3}{*}{0.659} & \multirow{3}{*}{0.434} \\
\hline & Customer Satisfaction & 0.597 & 13.693 & 0.000 & & \\
\hline & Switching Costs & 0.215 & 4.943 & 0.000 & & \\
\hline \multirow[t]{4}{*}{3} & (Constant) & & -0.164 & 0.870 & \multirow{4}{*}{0.661} & \multirow{4}{*}{0.437} \\
\hline & Customer Satisfaction & 0.602 & 13.771 & 0.000 & & \\
\hline & Switching Costs & 0.230 & 5.119 & 0.000 & & \\
\hline & Sat X SwCost & 0.059 & 1.309 & 0.192 & & \\
\hline
\end{tabular}

a Dependent Variable: e-loyalty

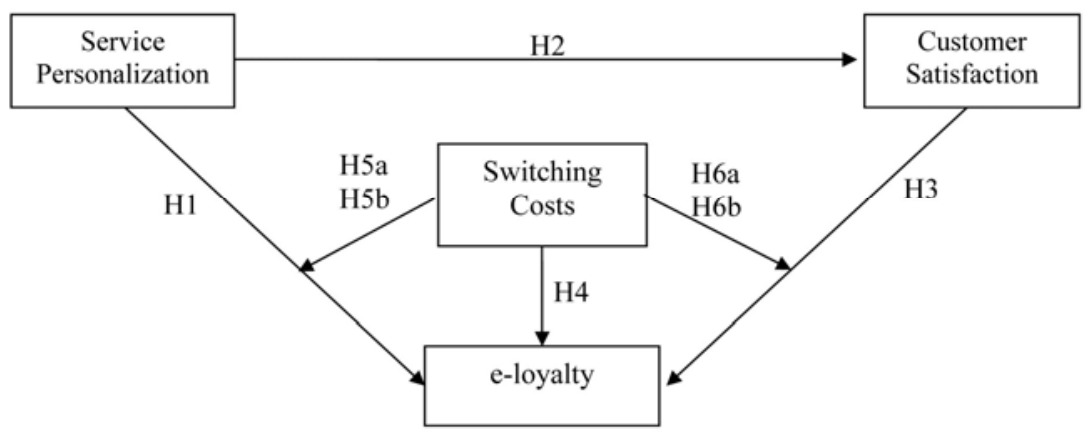

Figure 1. The Research Framework 